\title{
Epstein-Barr-virus-carrying lymphoma in a patient with ataxia-telangiectasia
}

\author{
ARI K SAEMUNDSEN, A IZZET BERKEL, WERNER HENLE, GERTRUDE HENLE, \\ MARIA ANVRET, ÖZDEN SANAL, FÜGEN ERSOY, MELDA ÇAĞLAR, GEORGE KLEIN
}

\begin{abstract}
An undifferentiated lymphocytic lymphoma of mesenteric lymph nodes occurred in a young boy with ataxiatelangiectasia. Two independent tests, Epstein-Barr virus (EBV)-cRNA/DNA hybridisation and EBV DNA/ DNA reassociation kinetic analysis, showed 53 and 68 EBV genome equivalents per cell respectively, which was compatible with an EBV-genome-carrying tumour. Whether this was a polyclonal lymphoproliferation or a monoclonal tumour could not be determined owing to lack of suitable material.

The presence of EBV genomes should be sought in lymphomas arising in ataxia-telangiectasia and other immunodeficiencies.
\end{abstract}

\section{Introduction}

Epstein-Barr virus (EBV) causes infectious mononucleosis and is regularly associated with the malignant cells of African Burkitt's lymphomas and nasopharyngeal carcinomas. It transforms normal B-lymphocytes into lymphoblasts with an unlimited life span. Although diploid and polyclonal, these lymphoblasts have a certain neoplastic potential, at least in immunologically highly privileged sites in experimental animals such as the brain of the nude mouse or the subcutaneous tissue of the newborn nude mouse. ${ }^{1}$

Healthy people infected with EBV keep their EBV-transformed B-lymphocytes under control during their lifetime. The mechanisms for this watertight surveillance are unknown; their study is of the greatest interest, since they reflect on the balance that may be achieved between a potentially oncogenic virus, the transformed cell, and the host. Probably at least part of the control is mediated by immune effectors.

In infectious mononucleosis tissues and organs are highly infiltrated by lymphoid cells, ${ }^{2}$ many of them atypical. In the usual, benign form of the disease these lesions and the atypical blood picture disappear spontaneously. It has been surmised that the EBV-specific killer $T$ cells that appear during the acute phase of the disease ${ }^{3}{ }^{4}$ are responsible for the rejection of most of the EBV-transformed B blast cells. This fits well with the

Department of Tumour Biology, Karolinska Institute, S-104 01 Stockholm 60, Sweden

ARI K SAEMUNDSEN, MSC, research associate

MARIA ANVRET, PHD, assistant professor of medical chemistry

GEORGE KLEIN, MD, DSC, professor, head of department

Department of Paediatrics, Hacettepe University Institute of Child Health, Hacettepe Children's Hospital, Ankara, Turkey

A IZZET BERKEL, $M D$, professor of paediatrics

ÖZDEN SANAL, MD, associate professor of paediatrics

FÚGEN ERSOY, $M D$, professor of paediatrics

MELDA ÇAĞLAR, MD, professor of paediatrics

Joseph Stokes, Jr, Research Institute, Children's Hospital of Philadelphia, School of Medicine, University of Pennsylvania, Philadelphia, Pennsylvania 19104, USA

WERNER HENLE, MD, professor of virology

GERTRUDE HENLE, MD, professor of virology fact that only a few of the atypical cells are EBV-determined nuclear antigen (EBNA)-carrying $B$ blasts while most are $T$ cells. ${ }^{5}$ In rare cases of fatal infectious mononucleosis rejection is apparently impaired and the lymphoid tissues of the patient harbour large numbers of EBNA-positive (that is, EBVcarrying) blast cells at the time of death. ${ }^{6-8}$

Purtilo et $\mathrm{al}^{9}$ suggested that some of the chronic or fatal forms of mononucleosis, and various lymphoproliferative conditions that often occur in boys-at least, the condition that they termed $\mathrm{X}$-linked lymphoproliferative syndrome-are due to the absence or breakdown of the immune mechanisms that normally control the proliferation of EBV-carrying cells. The correctness of this hypothesis and the occurrence of EBV-carrying lymphoproliferative disease in immunodeficiencies are best studied by testing affected tissues and organs for EBV genomes.

Ataxia-telangiectasia is a primary immunodeficiency disease with a high incidence of lymphoreticular malignancies. ${ }^{10}$ Patients with the disease are often characterised by high EBV antibody titres to viral capsid antigen and an increased incidence of antibodies against early antigen but low or non-detectable levels of antibodies against EBNA.11 12 Increased titres of antiearly antigen and antiviral capsid antigen with unusually low anti-EBNA titres signal a continuing process of EBV infection in conjunction with relative immunodeficiency.

We report on a patient with ataxia-telangiectasia who developed an EBV-carrying non-Burkitt's lymphoma.

\section{Case report}

A 9-year-old Caucasian boy was referred to Haceteppe Children's Hospital with an abdominal tumour discovered in mid June 1979. $\mathrm{He}$ had been born full term. The parents were first cousins and healthy. The patient had four healthy siblings. Ataxia was noted at around 2 years of age and became progressive. He suffered from recurrent respiratory infections and sinusitis. Within the six weeks before admission he complained of fever, anorexia, fatigue, and weight loss and could not walk without assistance.

Physical examination on 8 August showed an emaciated boy (weight $13 \mathrm{~kg}$, height $105 \mathrm{~cm}$ ) with a maculopapular eruption on the back, ocular telangiectasia, postnasal discharge, bilateral crepitant rales over the lung fields, and a firm, non-mobile $10 \times 15 \mathrm{~cm}$ mass in the right abdominal quadrant. His gait was ataxic.

Radiograms showed bilateral bronchopneumonic infiltrations and maxillary sinusitis. An intravenous pyelogram was within normal limits. Bone-marrow aspiration showed an increase in the myeloid series. Results of urine analysis and concentrations of blood urea nitrogen and uric acid were within normal limits. White cell counts varied between $2 \cdot 7 \times 10^{9} / 1\left(2700 / \mathrm{mm}^{3}\right)$ and $16.3 \times 10^{9} / 1\left(16300 / \mathrm{mm}^{3}\right)$ with absolute lymphocyte counts between 1.131 and $2.088 \times 10^{\circ}$ (1131 and $2088 / \mathrm{mm}^{3}$ ). Haemoglobin concentration varied between 7 and $11 \mathrm{~g} / \mathrm{dl}$. The results of skin tests were negative for streptokinasestreptodomase, candida, and purified protein derivative but positive for phytohaemagglutinin. The blastogenic response of his lymphocytes to phytohaemagglutinin, candida, and streptokinase-streptodomase, measured by the incorporation of ${ }^{3} \mathrm{H}$-thymidine into DNA, ${ }^{13}$ was low in comparison with the response in a healthy control (table). Serum immunoglobulin concentrations were IgG $570 \mathrm{mg} / 100 \mathrm{ml}, \operatorname{IgM} 125$ $\mathrm{mg} / 100 \mathrm{ml}$, and IgA $51 \mathrm{mg} / 100 \mathrm{ml}$. He was treated with antibiotics and blood transfusions.

When he had recovered from the respiratory infection laparotomy was performed on 17 August. A large tumour was seen originating from the intestinal mesenterium and displacing the right colon backwards. The small intestines were extensively infiltrated by tumour 
tissue. Biopsy specimens were taken from the tumour. Part of the specimens were fixed for histological studies and part frozen at $-70^{\circ} \mathrm{C}$ for nucleic acid hybridisation. This fixation was not suitable for EBNA tests. Histological examination showed a monotonous population of lymphoid cells with round or oval nuclei, considerable variation in nuclear size, a delicate, dusty chromatin pattern, and single large nucleoli. A relatively undifferentiated lymphocytic lymphoma was diagnosed. Chemotherapy was started with cyclophosphamide, vincristine, and prednisone on 22 August. He died of sepsis two weeks after the operation. Permission for postmortem examination was not obtained. mol sodium acetate $/ 1(246 \mathrm{mg} / 100 \mathrm{ml}), \mathrm{pH} 4 \cdot 4)$, and $500 \mathrm{U}$ of $\mathrm{S} 1 \underline{\underline{\sigma}}$ nuclease were added. Incubation was carried out at $43^{\circ} \mathrm{C}$ for one hour. 3 The S1-resistant material was precipitated with $10 \%$ ice-cold tri- $\underset{\mathbb{Q}}{\Omega}$ chloroacetic acid and collected on to Whatman GF/C filters and $c$ counted in a liquid scintillation counter.

Self-renaturation of the labelled probe in the presence of calf thymus DNA or cellular DNA from the EBV DNA-negative U698M lymphoma line was subtracted from each time point. The results were analysed using linear regression as described by Sugden et al. ${ }^{21}$ Dilution of the samples with calf thymus DNA was taken into account when calculating the EBV genome number per cell.

Blastogenic response in the patient compared with response in a healthy control

\begin{tabular}{|c|c|c|c|c|c|c|}
\hline \multirow{3}{*}{ Stimulators } & \multicolumn{3}{|c|}{ Patient } & \multicolumn{3}{|c|}{ Control } \\
\hline & \multicolumn{2}{|c|}{ Counts per minute* } & \multirow{2}{*}{ 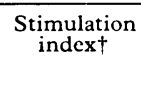 } & \multicolumn{2}{|c|}{ Counts per minute* } & \multirow{2}{*}{$\begin{array}{c}\text { Stimulation } \\
\text { index } \dagger\end{array}$} \\
\hline & Stimulated & Unstimulated & & Stimulated & Unstimulated & \\
\hline $\begin{array}{l}\text { Phytohaemagglutinin } \\
\text { Candida } \\
\text { Streptokinase-streptodornase }\end{array}$ & $\begin{array}{r}15744 \\
1968 \\
923\end{array}$ & $\begin{array}{l}1210 \\
1271 \\
1271\end{array}$ & $\begin{array}{c}13 \\
1.55 \\
0.73\end{array}$ & $\begin{array}{r}76177 \\
5986 \\
3676\end{array}$ & $\begin{array}{l}1702 \\
1025 \\
1025\end{array}$ & $\begin{array}{l}44 \cdot 8 \\
5 \cdot 84 \\
3 \cdot 59\end{array}$ \\
\hline
\end{tabular}

*Expressed per $10^{6}$ cells.

†Stimulation index $=$ counts per minute (stimulated)/counts per minute (unstimulated).

\section{Materials and methods}

Serum antibody titres to EBNA, the D and R subcomponents of the early antigen complex, and viral capsid antigen were determined by immunofluorescence methods. ${ }^{14-17} \mathrm{EBV}$ genomes were detected as follows.

\section{CRNA/DNA FILTER HYBRIDISATION}

Cellular DNA was prepared from the biopsy specimen by standard procedures ${ }^{18}$ and hybridisation to in-vitro transcribed and labelled EBV complementary RNA (cRNA) was carried out according to the method of Lindahl et al. ${ }^{19}$ Briefly, EBV DNA was transcribed in vitro by using Escherichia coli $\mathrm{RNA}$ polymerase and ${ }^{32} \mathrm{P}$-cytidine-5' - triphosphate $(400 \mathrm{Ci} / \mathrm{mmol}$; Amersham). Cellular DNA was fixed to nitrocellulose filters (10 $\mu \mathrm{g}$ to each), and the filters were incubated with 1-2 ng ${ }^{32}$ P-cRNA per filter. After RNase treatment and repeated washing, to remove unhybridised RNA, the filters were dried and counted. The counts hybridised were corrected to a DNA content of $10 \mu \mathrm{g}$. The DNA content on each filter was determined by the diphenylamine method. The average number of EBV genome equivalents per cell was obtained by comparing the counts retained by the sample filters with the counts retained by the filters containing DNA from the EBVpositive Raji cell line. DNA from the EBV-negative U698M cell line served as a negative control.

\section{REASSOCIATION KINETICS}

Purified EBV DNA (B95-8 substrain) was labelled in vitro with ${ }^{3} \mathrm{H}$-thymidine-5'-triphosphate $(40-60 \mathrm{Ci} / \mathrm{mmol}$; Amersham $)$ as described by Given and Kieff. ${ }^{20}$ The specific activity was $4-5 \times 10^{6}$ $\mathrm{cpm} / \mu \mathrm{g}$.

Hybridisation was carried out in $10 \mathrm{mmol}$ tris (hydroxymethyl) amino methane hydrochloric acid/1 $(158 \mathrm{mg} / 100 \mathrm{ml})$ with $1 \mathrm{mmol}$ EDTA/1 $(29 \cdot 2 \mathrm{mg} / 100 \mathrm{ml}), \mathrm{pH} 7 \cdot 5$. The samples to be tested were brought to the same concentration with calf thymus DNA $(2 \mathrm{~g} / \mathrm{l})$. After $0.01 \mu \mathrm{g}$ labelled EBV DNA had been added the sample was sheared by sonication and denatured by heat. It was then adjusted to $0.1 \%$ in sodium dodecyl sulphate and $1 \mathrm{~mol} / 1$ sodium chloride. Volumes $(20 \mu \mathrm{l})$ were sealed in micropipettes and incubated at $70^{\circ} \mathrm{C}$. Aliquots were removed periodically, the hybridisation reaction stopped at $-70^{\circ} \mathrm{C}$, and the samples stored at $-20^{\circ} \mathrm{C}$.

The fraction that remained single standard $\left(\mathrm{f}_{\mathrm{ss}}\right)^{21}$ was measured by digestion with $S 1$ nuclease (Boehringer Mannheim). Each $20 \mu 1$ sample was diluted to $100 \mu \mathrm{l}$ with $10 \mathrm{mmol}$ tris (hydroxymethyl) amino methane hydrochloric acid/1 $(158 \mathrm{mg} / 100 \mathrm{ml})$ containing $20 \mu \mathrm{g}$ denatured calf thymus DNA and $50 \mu \mathrm{g}$ native calf thymus DNA. The sample was brought to $1 \mathrm{ml}$ with $\mathrm{S} 1$ buffer $(2 \mathrm{mmol}$ zinc chloride/ 1 $(27.3 \mathrm{mg} / 100 \mathrm{ml}), 0.1 \mathrm{~mol}$ sodium chloride $/ 1(584 \mathrm{mg} / 100 \mathrm{ml})$, and 0.03

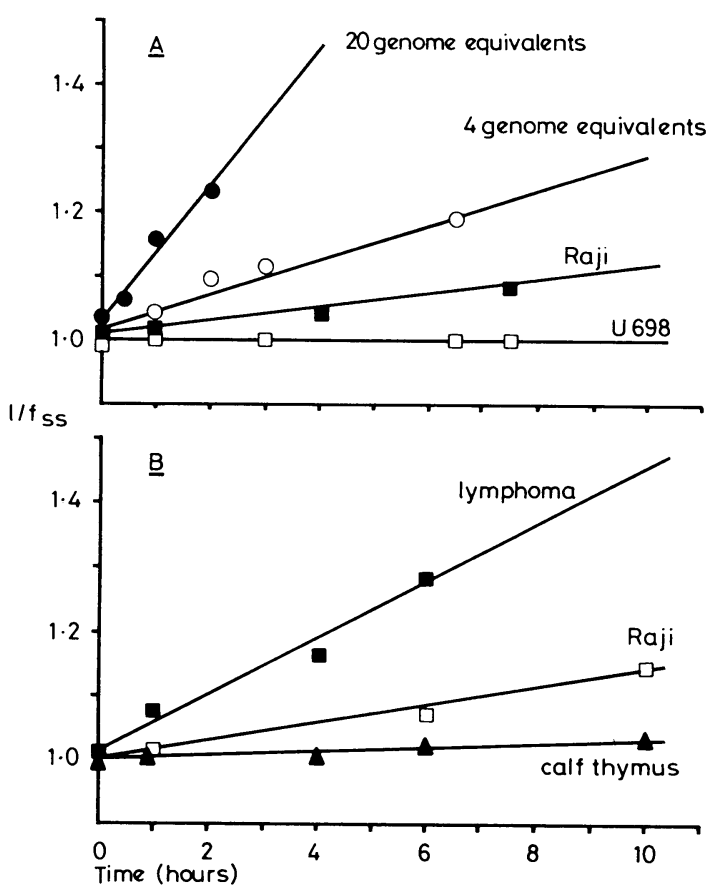

Determination of number of EBV genome equivalents in lymphoma biopsy specimen. $(A)$ Reconstruction experiment to determine the number of EBV genome copies in the positive Raji control. EBV DNA was added to calf thymus DNA to correspond to four and 20 genome equivalents per cell (one genome equivalent $=0.25 \mathrm{ng}$ EBV DNA $/ 10 \mu \mathrm{g}$ cell DNA), and hybridisation was carried out as described (see text). The Raji cell DNA was diluted with calf thymus DNA $(1: 20)$, and this mixture was found to contain two EBVgenome equivalents per cell. $(B)$ The number of EBV genome equivalents per cell in the tumour biopsy specimen was determined by comparing its slope with that of the positive Raji control (diluted as above).

\section{Results}

$E B V$ serology and nucleic acid hybridisation-EBV antibody titres in the patient were antiviral capsid antigen (IgG) $1 / 320$, anti-early antigen $1 / 10$ (D component), and anti-EBNA 1/40. While the antiviral capsid antigen titre was in the upper normal range, the detection of anti-D might be in line with an enhanced EBV-related process."11

Filter hybridisation-Four filter hybridisation tests were carried out. They showed a mean specific hybridisation of $1694 \mathrm{cpm}$, with a back- 
BRITISH MEDICAL JOURNAL VOLUME $282 \quad 7$ FEBRUARY 1981

ground of $681 \mathrm{cpm}$ subtracted for the EBV-negative U698M lymphoma line. This corresponds to an average of $53 \mathrm{EBV}$ genome equivalents per diploid cell.

Reassociation kinetics-DNA extracted from the EBV-carrying Raji lymphoma cell line was used as the positive control. The Raji cell DNA was diluted with calf thymus DNA $(1 / 20)$, and this mixture was found to contain two EBV genome equivalents per cell (figure $(A)$ ). Thus the Raji line contained 40 genome equivalents per cell. The DNA isolated from the lymphoma biopsy specimen was run in parallel with Raji cell DNA (figure $(B)$ ). The amount of EBV DNA in the specimen was determined by comparing the slopes of the two lines ${ }^{21}$ and correcting for the dilution $(1 / 12 \cdot 5)$ of the cellular DNA by calf thymus DNA. It corresponded to 68 genome equivalents per cell.

\section{Discussion}

Two independent tests, cRNA/DNA hybridisation and DNA/ DNA reassociation kinetics, concurred in showing the presence of between 50 and $70 \mathrm{EBV}$ genome equivalents per cell in the lymphoma biopsy specimen. This is comparable with values found in Burkitt's lymphomas and nasopharyngeal carcinomas ${ }^{22-24}$ and compatible with the interpretation that the patient had an EBV-genome-carrying tumour. Owing to the lack of suitable material we could not determine whether this was a polyclonal lymphoproliferation, as seen in fatal cases of infectious mononucleosis, or a monoclonal tumour, such as Burkitt's lymphoma. This distinction is of more than academic interest. EBVtransformed cells derived from infectious mononucleosis are polyclonal and diploid, whereas EBV-carrying Burkitt's lymphoma cells are monoclonal and regularly show tumourassociated cytogenetic changes. ${ }^{25}$ Most probably, diploid polyclonal lesions arise owing to the breakdown of host control mechanisms, whereas the monoclonal, chromosomally changed lymphoma reflects a progression to malignancy at the level of the target cell.

Further study of lymphomas arising in ataxia-telangiectasia and other immunodeficiencies for the presence of EBV genomes will be of great interest. Whenever appropriate specimens become available clonality and cytogenetic studies of the tumour should be carried out in parallel with tests for EBV genomes. We should be grateful if tissues could be made available, preferably as dry-ice-frozen biopsy specimens, and sent to our Stockholm laboratory.

Purified EBV DNA (B95-8 substrain) was prepared by Dr Meihan Nonoyama and kindly provided by Life Sciences Inc, St Petersburg, 33710 Florida, USA, under a contract from the Division of Cancer Cause and Prevention, National Cancer Institute.

This research was supported in part by the Haceteppe Child Health Foundation; by contract N01-CP-33316 and N01-CP-33272 from the Division of Cancer Cause and Prevention, National Cancer Institute; and by the Swedish Cancer Society.

The skilful technical help of Ann-Christine Synnerholm is gratefully acknowledged. We also thank Drs P Biberfeld and D Purtilo for the review of the histological sections of the biopsy material.

\section{References}

${ }^{1}$ Giovanella B, Nilsson K, Zech L, et al. Growth of diploid, Epstein-Barr virus-carrying human lymphoblastoid cell lines heterotransplanted into nude mice under immunologically privileged conditions. Int $\mathcal{f}$ Cancer $1979 ; 24: 103-13$.

${ }^{2}$ Carter RL. In: Biggs RM, de Thé G, Payne LN, eds. Oncogenesis and herpesviruses. Lyons: International Agency for Research on Cancer, $1972: 230-8$.

${ }^{3}$ Svedmyr E, Jondal M. Cytotoxic effector cells specific for B cell lines transformed by Epstein-Barr virus are present in patients with infectious mononucleosis. Proc Natl Acad Sci USA 1975;72:1622-6.

${ }^{4}$ Svedmyr E, Jondal M, Henle W, et al. EBV specific killer $\mathrm{T}$ cells and serologic responses after onset of infectious mononucleosis. Fournal of Clinical and Laboratory Immunology 1978;1:225-32.

${ }^{5}$ Klein G, Svedmyr E, Jondal M, et al. EBV determined nuclear antigen (EBNA)-positive cells in the peripheral blood of infectious mononucleosis patients. Int $\mathcal{f}$ Cancer 1976;17:21-6.
${ }^{6}$ Britton S, Andersson-Anvret M, Gergely P, et al. Epstein-Barr virus immunity in a fatal case of infectious mononucleosis. $N \mathrm{Engl} \mathcal{F} \mathrm{Med}$ 1978;298:89-92.

7 Virelizier JL, Lenoir G, Griscelli C. Persistent Epstein-Barr virus infection in a child with hypergammaglobulinemia and immunoblastic proliferation associated with a selective defect in immune interferon secretion. Lancet 1978;ii:231.

${ }^{8}$ Crawford DH, Epstein MA, Achong BG, et al. Virological and immunological studies on a fatal case of infectious mononucleosis. $\mathcal{f}$ Immunol 1977;119:1857-9.

${ }^{9}$ Purtilo DT, Hutt L, Bhawan J, et al. Immunodeficiency to the EpsteinBarr virus in the $\mathrm{X}$-linked recessive lymphoproliferative syndrome. Clin Immunol Immunopathol 1978;9:147-56.

${ }^{10}$ Kersey JH, Spector BD, Good RA. Primary immunodeficiency diseases and cancer: the Immunodeficiency-Cancer Registry. Int $\mathcal{F}$ Cancer 1973; 12:333-47.

${ }^{11}$ Berkel AI, Henle W, Henle G, et al. Epstein-Barr virus related antibody patterns in ataxia-telangiectasia. Clin Exp Immunol 1979;35:196-201.

12 Joncas J, Lapointe N, Gervais F, et al. Unusual prevalence of Epstein-Barr virus early antigen (EBV-EA) antibodies in ataxia-telangiectasia. $\mathcal{f}$ Immunol 1977;119:1857-9.

${ }^{13}$ Gelfand EW, Berkel AI, Godwin HH, Rocklin RE, David JR, Rosen FS Pernicious anaemia, hypogammaglobulinemia and altered lymphocyte reactivity: a family study. Clin Exp Immunol 1972;11:187-99.

${ }^{14}$ Henle G, Henle W. Immunofluorescence in cells derived from Burkitt's lymphoma. 7 Bacteriol $1966 ; 91: 1248-56$.

${ }^{15}$ Henle W, Henle G, Zajac BA, et al. Differential reactivity of human serums with early antigens induced by Epstein-Barr virus. Science $1970 ; 169: 188-90$.

${ }^{16}$ Henle G, Henle W, Klein G. Demonstration of two distinct components in the early antigen complex of Epstein-Barr virus-infected cells. Int $\mathcal{F}$ Cancer $1971 ; 8: 272-82$.

${ }^{17}$ Reedman BM, Klein G. Cellular localization of an Epstein-Barr virus (EBV)-associated complement-fixing antigen in producer and nonproducer lymphoblastoid cell lines. Int f Cancer 1973;11:499-520.

18 Pettersson U, Sambrook J. Amount of viral DNA in the genome of cells transformed by adenovirus type 2 . $\mathcal{F}$ Mol Biol 1973;73:125-30.

19 Lindahl T, Adams A, Bjursell G, et al. Covalently closed circular duplex DNA of Epstein-Barr virus in a human lymphoid cell line. $\mathcal{F} \mathrm{Mol} \mathrm{Biol}$ 1976;102:511-30.

${ }^{20}$ Given D, Kieff E. DNA of Epstein-Barr virus. IV. Linkage map of restriction enzyme fragments of the B95-8 and W91 strains of EpsteinBarr virus. F Virol 1978;28:524-42.

${ }^{21}$ Sugden B, Phelps M, Demoradzki J. Epstein-Barr virus DNA is amplified in transformed lymphocytes. F Virol 1979;31:590-5.

22 zur Hausen $\mathrm{H}$, Schulte-Holthausen $\mathrm{H}$, Klein $\mathrm{G}$, et al. EBV DNA in biopsies of Burkitt tumours and anaplastic carcinoma of the nasopharynx. Nature 1970;228:1056-8.

${ }^{23}$ Nonoyama M, Huang CH, Pagano JS, et al. DNA of Epstein-Barr virus detected in tissue of Burkitt's lymphoma and nasopharyngeal carcinoma. Proc Natl Acad Sci USA 1973;70:3265-8.

${ }^{24}$ Lindahl T, Klein G, Reedman BM, et al. Relationship between EpsteinBarr virus (EBV) DNA and the EBV-determined nuclear antigen (EBNA) in Burkitt lymphoma biopsies and other lymphoproliferative malignancies. Int 7 Cancer $1974 ; 13: 764-72$.

${ }^{25}$ Klein G. Lymphoma development in mice and humans: diversity of initiation is followed by convergent cytogenetic evolution. Proc Natl Acad Sci USA 1979;76:2442-6.

(Accepted 19 November 1980)

ONE HUNDRED YEARS AGO At a recent meeting of the Statistical Society, Mr Cornelius Walford reviewed the numbers and causes of deaths from accident, negligence, violence, and misadventure, in the United Kingdom and some other countries. Mr Walford was of opinion that violent deaths of various kinds had advanced with the progress of civilisation. New forces, as also increasing mechanical productiveness, rendered the risk to life and limb continually greater. The five great divisions in deaths of this class were those caused respectively by railways, in the working of mines, by mechanical fumes and compounds, and by asphyxia, or stifling, and by drowning. A sixth and important class remained-those which for various reasons could not be placed under the proper division to which they rightly belonged, as in the case of persons found dead without any means of determining the precise agency by which death had been occasioned. These were far more numerous than had been generally supposed. Railways were placed first in the enumeration, but they were not the cause of the greatest number of violent deaths. More persons were killed by horses and horse-accidents every year than by all the railways of the kingdom. The total of violent deaths registered annually in England and Wales is about 18,000, in Scotland about 3,000, and in Ireland about 2,000; and the non-fatal injuries are in the ratio of 100 to each fatal accident. (British Medical fournal, 1881.) 